\title{
Global versus Glocal Dimensions of the Post-1981 Indian English Novel
}

\section{Daniela Rogobete, University of Craiova, Romania}

Whether condemned or wholeheartedly embraced, globalisation has become the new bogeyman of this millennium, dividing the world into opposite camps, each trying to legitimise their arguments for or against. The Indian Novel written in English (INE) of the last decades of the twentieth century and the beginning of the twenty-first raises a number of questions when read against the 'globalising' paradigm. This article analyses the way in which the INE, in its evolution from a variety of local traditions steeped in the protean realities of India to the embrace of Western literary forms, has gradually become one of the most efficient vectors of passage from a multitude of regionally fragmented literatures written in local languages, to a cosmopolitan writing that subtly combines global and glocal dimensions. Considering the INE as a complex literary phenomenon, I dwell on the particular strategies of cultural legitimation it has used in its evolution, especially after 1981, which led it to share many of the characteristic features generally associated with the global novel. I also question both the degree to which the description of 'global novel' can be applied to the INE and the problematic issue of 'localism' and its literary representations.

Although the 'internalisation of English literature and language’ was a contested phenomenon in India, the emerging hybrid INE, and its remarkable use of local and global spaces as realms of emulation and contestation, contributed to the success of the national project of self-affirmation and cultural legitimation. The significant changes 
initiated within the realm of INE by Salman Rushdie’s 1981 Booker Prize winning novel Midnight's Children and continued by other remarkable Indian English texts show that, in this case, despite global recognition and circulation the balance between local specificity and universal issues, between national and diasporic identities and, finally, between regional and cosmopolitan perspectives, is yet to be attained in the INE.

\section{Thinking global, feeling local}

Seen as a normal stage in the evolution of modernity triggered by the advancement of media and technology, globalisation has been variously defined in terms of sameness versus otherness, space versus locality, deterritorialisation and interconnectedness, according to economic, political, social and cultural considerations. Starting from David Harvey’s (1989) concept of postmodern time-space compression and its globalising consequences, various theorists have tried to shed light upon one of the most controversial concepts of our time. They have emphasised its benefits-'the compression of the world and the intensification of consciousness of the world as a whole' (Robertson 1992: 8)—as well as its role as an ideological tool, highlighting its drawbacks that are related to a cultural leveling, a 'compression of cultures ... brought into contact and juxtaposition' (Featherstone 1995: 7). The newly created interdependence between the local and the global has triggered a feeling of 'global closeness' (Tomlinson 1999: 4) that is seen as either beneficial or destructive at the level of national and regional cultures.

Zygmunt Bauman, one of the major theorists of globalisation envisages the phenomenon as a particular manner of treating difference, given its reliance on a new international division of labour, a process of internationalisation of finance, new technological systems and the homogenisation of consumer markets (Bauman 1989). Bauman is also one of the many theorists who deal with the concept of glocalism and glocalisation in relation to globalism and globalisation. Initially referring to an agricultural method of adjusting farming techniques to local conditions, the term glocalism has gradually been taken over by business jargon where it defines globalising strategies adapted to local conditions (Iwabuchi 2002: 93). From this perspective glocalisation becomes ‘a blending of foreign and local’ (Straubhaar 2007: 149). Mike Featherstone mentions the connection between this term and the Japanese ability to indigenise anything foreign and globalised: 
If the term Japanisation of the world means anything, it is in terms of a market strategy built around the notion of dochaku or "glocalism." The term refers to a global strategy that does not seek to impose a standard product or image, but instead is tailored to the demands of the local market. This has become a popular strategy for multinationals in other parts of the world who seek to join the rhetoric of localism. (Featherstone 1995: 5)

'Global standardisation' is thus being replaced by what is generally seen as 'global localisation' or 'glocalisation.' Similarly, Arjun Appadurai theorizes the idea of 'global cultural flow' in relation to six categories at play in shaping cultural globalization- the ethnoscape, referring to the world of moving groups of people and their cultural crosspollination, the mediascape, related to the dissemination of information, the technoscape, related to global technological configurations, finanscape, defining the distribution of global capital and, finally, ideoscape, referring to the ideologies thus engendered (1996: 33-37).

The complex processes of cultural globalisation are generally defined in relation to cultural, linguistic or economic factors. Tomlinson, for example, speaks about global culture in terms of 'deterritorialisation,' reinforcing the newly defined connection between culture and the increasingly compressed physical space, and referring to cosmopolitanism and to a new form of 'complex connectivity' (1999: 2) between economy, politics and culture. In Tomlinson's opinion the utopian endeavour of creating a global culture through globalisation - that is, 'a single culture embracing everyone on earth and replacing the diversity of cultural systems that have flourished up to now' (1999: 71)—reveals its shortcomings in that the final result can only be a globalised culture instead of a global culture. The same idea is shared by Mike Featherstone who argues that the idea of 'global culture' still seems utopian since it is tightly related to a nation-state and to such values as homogeneity and integration, whereas 'cultural globalisation' refers to a broader concept that implies processes of cultural integration and disintegration that operate on transnational and trans-societal levels (1990: 1$)$.

Given the above conceptual approaches, the concept of the 'global novel,' usually related to post-colonial productions inherently 'born translated,' is generally thought to imply a wide range of literary endeavours that exceed local interest and appear to have a universal appeal. The 'global novel' also implies publication in multinational publishing houses, international recognition and circulation, the presence on book markets and fairs, and attendant favourable statistics related to the number of translations, sales figures, 
marketing strategies and international reading public receptions. When enlarging upon the possible definitions of the 'global novel,' J. M. Coetzee’s fictional author, Elizabeth Costello, speaks in contrastive terms, opposing regional and global literature and establishing style, audience and scope of relevance as three decisive factors in legitimising regional literature and giving it the status of global cultural production (Coetzee 2004). She draws attention to the fact that defining global literature according to the criterion of 'universality' provided by the choice of style and content necessarily and readily accessible to a global readership only proves the impossibility of the attempt to completely displace literature from its regional context and to project it onto a global scale. The necessity of 'immediate accessibility' also raises the issues of linguistic as well as cultural translations of regional texts: 'Yet how can you explore a world in all its depth if at the same time you are having to explain it to outsiders? ... It is too much for one person, it can't be done, not at the deepest level. That, it seems to me, is the root of your problem. Having to perform your Africanness at the same time as you write' (Coetzee 2004: 51). Costello’s remarks about the African novel can also be applied to Indian literary spaces since 'performing Indianness' and translating Indian languages, cultures and oral tradition are equally complicated tasks: 'A French or an English writer has thousands of years of written tradition behind him ... We on the other hand are heirs to an oral tradition' (2004: 44); and 'a novel about people who live in an oral culture is not an oral novel, just as a novel about women is not a women's novel' (2004: 53).

Critics have highlighted the dangers of globalisation in relation to fiction, mainly in terms of the loss of local specificity and national identity and the annihilation of regional and national literatures, given the so-called imperative to level their differences and embrace monologism. The most vehement anti-globalisation voices have defended literatures written in national languages, putting forward the argument that the 'perfect translation' is impossible, and they have pleaded for the freedom to rewrite one's own history, using one’s own literary tradition. These critical approaches include Thomas Friedman's The Lexus and the Olive Tree: Understanding Globalisation (2000) on the dangers of globalisation and 'unhealthy glocalism'; Mike Featherstone’s Undoing Culture: Globalisation, Postmodernism and Identity (1995); Peter Singer's One World: The Ethics of Globalisation (2004), and Mark Rupert's Ideologies of Globalisation: Contending Visions of a New World Order (2000). 
When analysed from economic and cultural perspectives and set against Appadurai's (1996) various scapes, the INE mainly produced after 1981 share many common features with the global novel defined by the critics noted above. The 'think global' part of the syntagm is sustained by a powerful combination of mediascapes and technoscapes that facilitates the access to global markets and global readership, and by an ideoscape that makes use of transnational and transcultural dimensions. At the same time, the 'feel local' part seems to be less powerfully represented by an ethnoscape identified with a substantial Indian diaspora that tends to ignore the multitude of significant regional voices. Though protean and polyphonic, playing on an Indianness difficult to define, translate and contain within theoretical frameworks, the INE is often accused of letting itself be wholeheartedly engulfed by globalism.

The Western world has always tried to simplify India’s immense diversity and make it more accessible through a 'unifying project' engendered by what Sara Suleri calls the 'anxiety of empire' and designed to counteract the 'unreadability of India' (1995: 6). Critics have often drawn attention to the inappropriateness of general terms such as 'Indian literature' and 'Indianness' that only perpetuate erroneous Oriental representations and offer simplified representations of the multitude of Indian regional literatures and cultures. From this perspective, even the denomination of the 'global Indian novel' seems doomed from the start as it tends to first, focus only on texts published and circulating outside India, and second, to overlook the large body of literature produced in regional languages. The temptation of placing an ideally and falsely unitary India into a 'generalised elsewhere' and a 'global anywhere' (Meyrowitz 2004) is amplified by increased media technologies and the pressures to indulge a Western readership that might get lost in the difficult translation of India's traditions of orality and the country's cultural diversity. In relation to Indian literatures glocalism, generally defined as the strategy of combining the local and the foreign, seems to account for features most often attached to cultural borrowing, appropriation, hybridisation and indigenisation.

Friedman, for example, identifies glocalism thus:

The ability of a culture, when it encounters other strong cultures, to absorb influences that naturally fit into and can enrich that culture, to resist those things that are truly alien and to compartmentalise those things that, while different, can nevertheless be enjoyed and celebrated as different. The whole purpose of glocalising is to be able to assimilate aspects of globalisation into your country and culture in a way that adds to your growth and diversity, without overwhelming it. (Friedman 2000: 326) 
Regional literatures and Indian English literature are often placed in stark opposition on account of the languages they use, the ideological stance they adopt or the perspective they embrace. Nonetheless regional literatures and Indian English literature share the aim of offering different representations of the 'idea of India.' It all comes down to the type of 'idea' the writers want to engender, the readers they choose to address and the cultural-political identity they create. As Gayatri Chakravorty Spivak argues, the relationship between the writer of 'vernacular' and the writer of Indian English literature is 'a site of class-struggle ... a struggle in the production of cultural or cultural-political identity’ (1996: 126-127) and more recently a site of competing 'localisms.' Moreover P. P. Raveendran argues that these writers, sharing the same nationality but with different 'contexts, mindsets, experiences, lifestyles, languages and sensibilities ... dwell in different Indias, and to speak of them as sharing a common Indian literature would be, to adapt Sahitya Akademi's dictum on the oneness of Indian literature, to say that they are writers divided by the same literature' (Raveendran 2006: 2563).

The worldwide recognition of Indian literature today is generally taken as a good example of successful integration and assimilation, a complicated and problematic process initiated during the nineteenth century with growing interest in Sanskrit writings and Indian mythology, and the awareness that the multitude of regional languages made it impossible for any local non-English speaking Indian writer to succeed in Western markets. The illustrious exception of Rabindranath Tagore, whose Gitanjali (1912) was awarded the Nobel Prize for Literature in 1913, marked a crucial moment in the evolution of the Indian literature written in English and turned him from a Bengali writer translating his own plays and poems into English into a widely recognised and appreciated member of the Western literary canon. Srinivasa Iyengar described Tagore’s remarkable achievement as ‘but the beginning of a drama of recognition on a global scale to which there cannot be many parallels in literary history' (1962: 84). These words turned out to be prophetic as the struggle of Indian authors for global recognition continued for almost a century and involved a multitude of literary and publishing strategies adjusted to the particular circumstances of the Indian context.

The immense popularity INE enjoys in the West today is paralleled by the critical voices that denounce its purported lack of authenticity, its presumed promotion of a 
false image of India, its either excessively romantic or denigratory characteristics, and its supposed perpetuation of colonial stereotypes. Such criticism is generally directed against what some observers regard as the 'inauthenticity' and falsehood engendered by the requirements of globalisation, and a concomitant indulging of Western taste.

Chandrahas Choudhury (2009: 96), for example, argues that: 'What readers around the world frequently find instructive, fresh and moving about Indian novels available to them in English is often experienced by Indian readers as dull, clichéd and superficial.' What Choudhury formulates as the paradox of INE is restated by Harish Trivedi, who also draws attention to the absurdity of a 'globally constituted' post-colonial discourse that 'hardly begins to address either the post-colonial Indian reality or its post-colonial literature except perhaps in some incidental and tangential ways’ (2000: 243).

In its evolution, Indian literature written in English has received various denominations, most of them charged with ideological connotations, and many dogged by the critical disputes I have already noted above. Interestingly, Srinivasa Iyengar analysed most of these terms in his now canonical work Indian Writing in English from 1962. The general term, 'Indian literature', proved its inappropriateness due to its ambiguous reference to literatures written in any of the regional languages, including English. 'Anglo-Indian literature' referred to texts produced by the British residents in Indialater by people of mixed races treated as 'Bastards of the Raj' or 'Midnight's Orphans' (D’Cruz 2003: 106); ‘Indo-Anglian literature’, a term coined by J. H. Cousins (1883) and popularized by Iyengar (1962), defines the body of Indian fiction written in English. Even within this category, the scholar and major force in Kannada literature, Vinayaka Krishna Gokak, adds the denomination of Indo-English to designate works produced in regional languages and translated into English, whereas Indo-Anglian remains mostly attached to texts produced in English by Indian writers (Gokak 1970). M. K. Naik (1982) added 'Indian English literature' as a better alternative for the less inspired 'Indo-Anglian literature’ (also see Khair 2001). In the twenty-first century, acronyms such as IWE (Indian Writing in English), IEL (Indian English Literature) and INE (Indian Novel written in English), the latter my preferred term, are also in use.

Aside from debates over nomenclature, another critical point that is generally brought into discussion about Indian English literature is the impossibility of the project it proposes, that of trying to suggest an essential Indianness through a basically Western 
literary endeavour. In the analysis of INE and the degree of compromise it is forced to make, the criterion of 'authenticity' (mostly attached to regional literatures) is generally replaced with 'specificity,' assessing the extent to which diaspora writers and their novels succeed in preserving local specificity, truthfulness in any language, the capacity to lead others to a 'renewal of consciousness' (Anand in Naik 2009: 41) and to prophesise. One possible solution for the current crisis of the INE seems to be a glocal fictional formula that would encompass both the diasporic, cosmopolitan representations of India and its local portrayals that are produced by regional literatures.

\section{From Anglo-Indian to Indian English fiction}

The nineteenth century is considered to be the beginning of modern Indian literature given the century coincided with the introduction of the English language and novel, and, perhaps, the initiation of a 'globalising literary project' avant la lettre through assimilation, integration and internalisation. Throughout its history, India has built a solid reputation as an assimilator, achieving a balance between tradition and modernity, cultures and religions, pre-colonialism and colonialism. Purity-whether related to ethnicity, religion or literary genres and styles—-has never been a highly appreciated value on the Indian sub-continent. Eclecticism, inclusiveness and plurality have instead been the stable foundations for India's diverse cultures.

When analysing the evolution of the Indo-English novel, Fawzia Afza-Khan (1993) discusses the articulations of various 'strategies of containment' as theorized by Fredric Jameson (1981) and Edward Saïd (1978) in relation to Indian English literary productions. Afza-Khan critiques the ideology of containment visible in many Indian English novels which she relates to the perpetuation of cultural and historically-biased perspectives and erroneous assessments of the Other; she also identifies the operations of an ideology of liberation focused upon the return to a mythical mode and to a reevaluated and mythologised past. She thus argues that the sometimes self-imposed containment within such a stereotypical representational framework can lead to imitation of colonial patterns, or what she calls a 'self-hating' literature. (1981: 32). Vidiadhar Surajprasad Naipaul, Afza-Khan states, is representative of this type of literature due to his tendency to adopt a very critical position on the problematic realities of the colonies and to confine the 'featureless' India of his childhood to a dark space of magical thinking and petrified existence (1981: 32). 
Afzal-Khan also refers to two fictional modes recurrent in Indian texts written in or translated into English: the realist and the mythic. This is helpful: the entire history of INE, a hybrid cultural formation, is often analysed as an intricate process of oscillation, coexistence or mutual exclusion of the realistic and the mythic modes. The need to abandon the English novelistic formula seems to have arisen from the incapacity of such a 'pure' genre to render the ambiguity and alienation produced by post-colonialism and its powerful effects upon the culture, language, national identity and social life of Britain’s colonies. The resulting ‘formula of hyphenation’ (Appadurai 1993: 803)— exemplified by such terms as Anglo-Indian—was an attempt to reconcile the English language, culture and its unitary and canonical literary tradition, and a multi-sided India, plural in terms of languages, literatures, cultural spaces and identities. It also tried to better depict the protean reality, the extreme diversity, the epic extent and eclectic mode of Indian thinking. Used and abused, assimilated and metamorphosed, the English novel (as well as the English language) has undergone drastic transformations in India. These changes were often embraced by authors in an attempt to make the novel 'engulf' the multitudes of India and thus achieve the almost impossible task of grasping the country's infinite variety, of condensing 'India' within the limited and limiting dimensions of a novel written in the colonisers' language but bearing the sound of so many Indian regional languages and specificities.

The evolution of the Indian writing in English was a long and dramatic process initiated during India’s literary 'Renaissance,' widely regarded as centred on Bengal and dating from the mid-nineteenth century to the 1940s. The intensive study of the English language and literature during this period had the unexpected effect of both encouraging INE and giving literary creations in regional languages a new impetus. Most of India's important writers in this period were bilingual, meaning they could choose to write in regional languages and then translate their texts in English, or write only in English. The literary tradition consolidated during the 'Renaissance' in the second half of the nineteenth century and the first half of the twentieth advocated the regeneration and modernisation of Indian culture through the combined processes of a return to tradition and a critical assessment and assimilation of Western principles. The 'Renaissance' period promoted such authors as Bankim Chandra Chattopadhyay (the father of modern Bengali prose), Henry Derozio (whose poetic work combined his romantic love for India and the critical spirit of a social reformer), Michael Madhusudan Dutt (who chose 
to continue the romantic tradition and to write in Bengali and English), and Toru Dutt, who rendered the subtle flavours of India into English verses by writing poems that oscillated between melancholy and exuberance, magic and reality, and by translating Sanskrit tales and legends and popularizing them in the West. Sri Aurobindo, the Indian poet, philosopher, politician and Yogi, as well as Sarojini Naidu, the Nightingale of India, continued to combine social criticism, political agitation and poetic lyricism in the attempt to awaken national consciousness and fuel hope in what such authors regarded as a divine humanity. The legacy of local representations of India thus engendered either by English Indian texts or by works produced in vernacular languages marked a transition from the picturesque and mostly romantic depictions of India that characterised earlier writing to a greater social and political critical awareness, and to more realistic portrayals of different Indian communities and regions.

During the first decades of the twentieth century writers emphasised the redefinition of national identity and the cultural remapping of Indian spaces according to the ever increasing indentured labour and diasporic movements, processes of cultural hybridity and the rise of new political reconfigurations. The 'literature of concern' based on human commonality further stressed the shift to simplicity and realism and created ambiguous responses to the problematic combinations of myth and realism, tradition and Westernisation, as in the novels and short stories written in Urdu and Hindi by Munshi Premchand, who succeeded in adapting Indian topics of social interest- the hard life of Indian peasantry, women's plight and political corruption-to Western literary styles, and Mulk Raj Anand, often regarded as the founder of the Indian English novel, ${ }^{1}$ famous for his realistic portrayals of the Indian poor. In the works of such authors, myth stood for spirituality, mysticism, wisdom; but it also gestured toward resignation, stasis, isolation in tradition. On the other hand, realism was taken to stand for rationalism, progress, flux, change, but also de-Indianisation, Westernisation, excessive materialism and mercantilism.

Raj Anand, R. K. Narayan and Raja Rao managed, in spite of the difficulties engendered by the Independence Movement, to boost the INE and to gain international recognition. Anand's humanism and enthusiastic nationalism, and his social criticism-

\footnotetext{
${ }^{1}$ Note that the first Indian novel ever written in English was Rajmohan's Wife by Bankim Chandra Chattopadhyay; it was serialised in the periodical The Indian Field in 1864 (Mehotra 2003: 12). The novel was published as a monograph in 1904, some ten years after the author's death.
} 
evident in the novels The Untouchables (1935) and Coolie (1936)—and Raja Rao's mixture of history and myth, of philosophy and social concern, in the description of rural India in the novel Kanthapura (1938 [1966]), marked a new direction in the evolution of INE, deeply rooted in Indian historic and social realities but attuned to Western stylistic expression. Steeped in Indian national tradition, relying both upon myth in all its coordinates - tradition, religion, mysticism, community-and critical realism, R. K. Narayan's fiction achieved an important quality that was resumed and rediscussed in post-1981 literary productions: the inner balance between self and society, individuality, social awareness and responsibility, and local specificity and tradition on the one hand and 'global' topics and themes on the other.

The post-World War Two generation of Indian writers continued to dwell on different aspects of Indian social or domestic life. Some offered insightful analyses of the impact of history and politics on everyday life, as exemplified by Khushwant Singh's seminal portrayal of Indian rural life in the wake of the Partition in Train to Pakistan, from 1956. Others dealt with the social and cultural clashes of Eastern and Western values, for instance, Kamala Markandaya’s depictions of Indian urban and rural societies affected by the advent of Western modernisation in such novels as Nectar in a Sieve (1955), Some Inner Fury (1956) and A Handful of Rice (1966). A third concern was with the tragic dimensions of people's confrontations with the economic, social and bureaucratic evils of the day, typified by Bhabani Bhattacharya's novels from 1947 through to 1966. Such authors prepared the literary world for the new generation of Indian writers, who were to take the Western canon, market and readership by storm, re-discussing the problematic issues of Indian multiple identities, of migrant and diasporic experiences, of marginalisation and cultural hybridisation.

The urgent necessity to go global, to acquire international visibility and enjoy circulation on global markets has created a rift between Indian writers producing texts in regional languages or Indian-based writers (Arundhati Roy, Shashi Tharoor, Raj Khamal Jha, Manju Kapur and Aravind Adiga) and representatives of the Indian diaspora: Salman Rushdie, Amitav Ghosh, Anita Desai and Kiran Desai (New York), Gita Mehta (New York/London/New Delhi), Vikram Chandra (Oakland), Rohinton Mistry (Toronto), Vikram Seth (Salisbury, UK), V. S. Naipaul (Wiltshire, UK), Hanif Kureishi (London), Jhumpa Lahiri (Rome), and Hari Kunzru (UK). Though not 
enjoying international critical acclaim, literary texts in vernacular languages are considered to possess a higher degree of authenticity, objectivity and relevance as compared to diasporic productions deemed inauthentic, artificial and biased. This dichotomy has given rise to a long lasting controversy that finally seems to come down to a dispute of principles between localism and cosmopolitanism.

Diasporic writers seem more inclined to focus on the cultural clash between India and the Western world and on its impact on people caught between spaces and identities, between the moral values inspired by the mythic imagination and individualism and the ones inspired by social involvement and responsibility. A growing awareness of the necessary acceptance of the colonial past, of the impossibility of a unifying project that might describe India as a coherent whole perfectly translatable and adjustable to Western readers' tastes and understanding also brought about the recognition that any essentialising fictional strategy attempting to depict Indian diversity is doomed to fail.

\section{Whose localisms are these, anyway?}

The novel, as a literary genre, has always had an inherent global feature visible in its global expansion during the eighteenth and nineteenth centuries on a par with Western Europe's colonial expansion and its appropriation by most of the peripheral spaces. Here, 'the modern novel first arises not as an autonomous development but as a compromise between a Western formal influence (mostly French or English) and local materials’ (Moretti 2000: 58). The ongoing debate concerning global literature and the various perspectives from which it has been defined has made theorists wonder whether this concept is a new reformulation of the old notion of world literature or another step in its evolution. In his groundbreaking analysis of the novel in relation to the historical process of globalisation and its discourses, Mariano Siskind suggested two models of analysis - the globalisation of the novel and the novelisation of the global (2010: 336360), models that can also be applied to INE. These conjoined aspects regard the novel as a hegemonic literary genre of modernity leading to global networks of transmission and reception and to a systematic production of images of a globalised world, textualised in novels.

The ideal goals global literature sets out to achieve are connected to the creation of a global space of cultural consensus and coexistence including literary productions coming from all the regions of the world. As products of 'the infinitely varied mutual 
contest of sameness and difference' (Appadurai 1990: 308), they should promote a global, essentialised concept of universality, transcend national 'locality' and narrativise a modern, reconciled cosmopolitan world in possession of a globalised literary canon.

To the often criticised attempt to find a globalising formula of cultural essentialisation, INE responds with its 'un-essentialisable' plurality. There is no formula for a perfect leveling and assimilation of so many 'Indian essences'-Assamese, Bengali, Gujarati, Hindi, Kashmiri, Kannada, Maithili, Malayalam, Marathi, Oriya, Punjabi, Sindhi, Tamil, Telugu, Urdu, not to mention Sanskrit—-best suited for such a hyphenation. Hence the difficulty in assessing this hybrid novel following either Oriental or Western criteria of critical evaluation, a dilemma first stated in 1962 by Srinivasa Iyengar, still relevant today:
Shall we judge it as English literature because it comes to us with an English skin (though a little tanned, shall we say, by the tropical Sun), or shall we judge it as Indian literature because it is, after all, the creation of Indians? ... There are peculiarities of Indian life and experience and speech that don't easily admit of translation into English terms. If the translation is not attempted, one fails in one's duty as an Indian; if the attempt doesn't succeed, if the result is an exotic, an oddity, an excrescence or an absurdity, one fails as a writer in English. (Iyengar 1962: 19-20)

In order to avoid falling 'between the stools,' Iyengar suggested a compromise, that a 'new mutation' be operated in both fictional and critical realms. This 'experimental new literature' was necessary in order to reflect the conflicting realities of India and at the same time the deeply felt need for a new critical perspective. The problem of authorship in the case of these hyphenated novels highlights the strange situation of their hyphenated authors (British-Indians, Indian-Americans, Indian-Canadians) that underlines an obvious crisis of identity discussed by Indian critics. The general atmosphere of scepticism built around authors writing about India but living outside it and around their capacity to faithfully depict India, made other writers such as Hari Kunzru deny his Indian roots and declare himself a British writer.

Indian English literature has not yet succeeded in reaching that reconciled space of absolute cultural consensus promoted by global literature, since the literary productions of the Indian diaspora and the frequent redefinitions of national identity they propose have led to ongoing debates over the legitimacy of those representations of a country one has deliberately left behind, over the false pretences of a unitary image of India and over the readership they choose to address. The controversy between Salman Rushdie and Amit Chaudhuri is a good example in this regard. Rushdie's statement in the 
preface to The Vintage Book of Indian Writing (Rushdie \& West 1997: x) that INE proves to be 'a stronger and more important body of work than most of what has been produced in the " 16 official languages” of India,' and that it represents 'the most valuable contribution India has yet made to the world of books,' is illustrative of a particular Western perspective on Indian literatures. Amit Chaudhuri's reply came in the preface of The Picador Book of Modern Indian Literature he edited where he interpreted the trope of 'ideal hybridity' embodied by INE as a pretext for the West to offer a 'reinterpretation of itself' and its 'historical quest' (Chaudhuri 2001: xxv). Beyond such disputes, Tabish Khair identifies a 'degree of commonality between Indian English novels and regional ones, based on references to a shared heritage of Indian classics’ (2001: 50) providing common topics, strategies and perspectives.

The globalising strategies generally promoted by the global novel in its attempt to devise formulas of essentialised representations and all-encompassing tropes that might, for instance, generalize the experience of post-colonialism, found their specific application in Indian English Literature. While Indian writers have found that the formula of adhering to cultural globalisation is not exempt of criticism and contestation, it however legitimated one side of India's struggle to find the perfect balance between so many conflicting identities, languages and cultural, political and historical dimensions.

Magic Realism has been universally embraced as a globalising strategy due to its wide spread from Latin America to Asia and Europe and to its capacity to preserve local specificity and package it into a globally appealing exoticism. Its remarkable success with the literature of former colonies translates the tendency to view it as providing the best suited narrative metaphor of a post-colonial nation. One major endeavour in Indian English fiction has thus been the attempt to preserve specificity by using mythologymyths mostly functioning as 'digressive techniques' as in Rushdie's case, or as 'structural parallels' in Narayan's and Rao's fiction, according to Mukherjee (1974: 131) — and the historic values of the past. But this looking back is never simple and unproblematic as it often challenges these very myths and demythologises traditional heroes and historic events. Salman Rushdie is among the first writers to have used myth as a strategy of liberation, a means of avoiding 'history petrification' (Afzal-Khan 160). Blending myths and history, reality and fantasy corresponded to a long tradition of 
eclecticism that excluded monologism and purity. In comparison with the Indian epic and poetic tradition oriented toward long, winding heroic sagas, with interminable digressions and side stories, remnants of an ancient oral tradition, the novel brought concision, cohesion and a new focus upon the realism of everyday life.

Perhaps the most widely discussed literary strategy that continues to divide critics is that of Indianising English. It is by no means a unique phenomenon given that after the linguistic unification of English (1707) and its spread around the globe through colonisation a variety of ‘world Englishes’ was engendered (Kachru 1996: 136-138). In India this corresponded to the Raj phase of the hybridisation of English, with very important consequences upon culture. Through linguistic assimilation and internalisation, India has succeeded in shaping English — the official language of globalisation-according to its needs.

Raja Rao was among the first Indian writers whose stated intention was to use the English language in such a way as to reshape it according to the rhythm and inflexions of his vernacular Kannada. His highly acclaimed endeavour, articulated in The Meaning of India (1996), was that of translating India into a foreign language while preserving its 'essence' as far as possible, keeping in mind the fact that India is not a desa but a darsana, not a country, but a perspective in need of a fresh idiom that would combine the mythical, the poetical and the political. Rao's use of English has been a valuable source of inspiration for many post-1981 authors as it opened new, unexpected grounds for linguistic innovations and strategies of self-affirmation. In the Foreword to Kanthapura he stated the difficulty a writer has to face when trying to translate Indianness:

\footnotetext{
One has to convey in a language that is not one's own the spirit that is one's own. One has to convey the various shades and omissions of a certain thought-movement that looks maltreated in an alien language. I use the word "alien," yet English is not really an alien to us ... After language, the next problem is that of style. The tempo of Indian life must be infused into our English expression, even as the tempo of American or Irish life has gone into the making of theirs. We, in India, think quickly, and when we move we move quickly ... we tell our interminable story ... (Rao 1966 [1938]: n. p.)
}

Linguistic liberation envisaged the creation of diverse variants of English (interlanguages) meant to provide the proper transition between a metropolitan language felt as imposing and stifling, and a reincarnation of the same language remoulded after the rhythm, structure and metaphoric patterns of native languages. Indianised English was 
the solution found for the perpetual dichotomy between pre-colonial recuperation and post-colonial syncretism (Ashcroft, Griffith \& Tiffin 2002: 29) and the opposite danger of getting stuck and isolated into a revived pre-colonial past ignoring contemporary multicultural realities. Linguistic liberation has also led to an opening up of the Western canon, triggering profound changes in world literature and influencing the reception of new literatures written in English. Manipulating and mongrelising English was an attempt to achieve a different type of decentralisation and legitimation by challenging the central position of the colonial language and offering instead a multiplicity of 'Englishes’ through indigenisation, creolisation, pidginisation, Indianisation and relexification.

\begin{abstract}
We can't simply use the language in the way the British did; ... it needs remaking for our own purposes. Those of us who do use English do so in spite of ambiguity towards it, or perhaps because of that, perhaps because we can find in that linguistic struggles taking place in the real world, struggles between the cultures within ourselves and the influences at work upon our societies. To conquer English may be to complete the process of making ourselves free. (Rushdie 1991: 17)
\end{abstract}

Along with other writers who made use of Indianised English (G. V. Desani, Bharati Mukherjee, Uma Parameswaran) and advocated the adaptation of English to native linguistic needs, Raja Rao praised the flexibility of English; he gave it the same sacred status as Sanskrit, claiming that language is 'an accidental thing' and what really mattered was ‘the authenticity of experience' (Jussawalla \& Dasenbrock 147). In his turn, R. K. Narayan saw English as the proper medium of cultural exchange, stating that 'the English language, though sheer reliance and mobility, is now undergoing a process of Indianization in the same manner as it adopted US citizenship over a century ago, with the difference that it is the major language there but here one of the fifteen' (1979: 22). Anita Desai spoke about an 'expanded' version of English resulting, after its 'buggering,' into a 'patchwork of languages' that might facilitate the linguistic and cultural cross-over (1994: 87). Angela Carter considered this linguistic transformation of English into Hinglish 'the ultimate revenge of the colonised' (1996: 208).

The year 1981 was generally acclaimed as the moment in which the INE was affirmed and legitimated, the moment when India finally made its voice (though speaking in English) heard on the international literary stage, imposing its particular combination of local specificity and universal human values, Western perspectives and Eastern counter perspectives, diasporic identities and hybrid spaces. The Booker Prize and other 
international prizes variously awarded to a series of Indian authors ${ }^{2}$ came as a meritorious recognition of the literary value of INE. These prizes, however, cemented the idea that Indian literatures could be represented by texts produced in English that enjoy a high degree of international visibility to the detriment of other productions in vernacular languages, authored by remarkable writers. Rushdie’s Midnight's Children became emblematic of the impressive post-1981 metamorphosis of the novel, coming as a response to the crisis of the fictional genre in Indian English literature and to the search for a new novelistic idiom that would 'engulf multitudes,' redefine national identities and map out cultural, political and linguistic spaces. Built on a highly critical and idiosyncratic synthesis of postmodern narrative strategies and post-colonial issues, and a subtle combination of cultural, mythological, religious and political elements, Midnight's Children triggered a genuine Rushdie-mania and a huge interest in Indian cultures and literatures with a particular focus on Indian literature written in English. This interest was further intensified in the following years by the many positive critical studies, commentaries and analyses dedicated to the literary productions of Indian authors belonging to the younger generation, residing in or outside India.

The INE embraced in fact a multitude of strategies and perspectives, besides the cosmopolitan approaches displayed by Salman Rushdie’s and Amitav Ghosh’s novels and the rhetoric of exile and its redefinitions of identity, home and away (as illustrated by Bharati Mukherjee, Shiv K. Kumar, Bhabani Bhattacharya and Nayantara Saghal). The criticism of a Westernised, excessively cosmopolitan INE that favours migrant perspectives and dwells on clashes of cultural values rather than on topics of immediate Indian interest had the effect of proliferating the texts depicting Indian social realities. Contemporary INE displays a wide range of such concerns: caste-based conflicts (Arundhati Roy ${ }^{3}$ and Rohinton Mistry), class and gender inequalities (Anita Desai, Manju Kapur), the Indian countryside (Kiran Desai), the mysterious recesses of Bombay (Vikram Chandra, Altaf Tyrewala) and the huge discrepancies between the rich and the poor (Aravind Adiga and Vikas Swarup). The plurality of 'localisms' thus engendered, promoted indeed a multifaceted image of global India, closer to its complex diversity but equally problematic. Even highly acclaimed novels such as Aravind

\footnotetext{
2 The 1975 Booker Prize was awarded to the German writer, Indian by marriage, Ruth Prawer Jhabvala for her novel Heat and Dust.

${ }^{3}$ On account of her political activism and social criticism, The New York Times declared Arundhati Roy to be 'India's most impassioned critic of globalization and American influence' (Dugger 2001).
} 
Adiga's The White Tiger (2008) or Vikras Swarup’s Q\&A (2005), that tried to demolish consecrated stereotypes and focus on lower-class individuals ascending the social ladder, were not exempt from criticism. The representations of poverty here were once again treated as inauthentic since they present the West with a sordid reality comfortably located in a distant and circumscribed 'localism' that does not pose the threat of contamination. The new mutations of 'localisms' attuned to Western phobias and delights become emblematic of Friedman's warning against the perils of 'unhealthy glocalism' triggered by an exacerbation of localisms that act as 'the cancer virus that fool you into thinking something belongs, but doesn't' (2000: 328).

Most of the post-1981 Indian novels in English written by representatives of the Indian diaspora in Europe and North America met with warm critical acclaim for their narrative and representational strategies that appealed to a global market and readership and at the same time with violent criticism for their somehow restrictively essentialised understanding of India. These critical voices claim that the globalising strategies they use are relying upon 'national allegories' and metaphoric images meant to mediate the conflicting aspects of Indian multiplicity.

Though criticised for their attempts to create a simplified image of a falsely unitary India, for preserving a convenient distance and writing in and for the West about a long forsaken Easternness (thus translating India for the Westerners instead of explaining India for the Indians themselves), the present generation of writers of Indian descent have achieved global recognition, affirming the legitimacy and undeniable worth of a novel that tries to combine Indian imagination and local specificities with the Western analytical mind. Nevertheless, this idiosyncratic combination of Western and Eastern values is meant-beyond the desire to fascinate and conquer the West—-to underline India’s eclecticism and multiplicity, and finally, its eternal untranslatability.

\section{Conclusion}

In achieving its present status of worldwide recognition, the Indian English novel has made a long, meandering journey that took it from the appropriation of the English novel during the nineteenth century and the first Indian novel written in English up to the unanimously celebrated and innovative fictional formula based on a combination of genres, cultural values and perspectives, cast in an idiosyncratic idiom. 
Whereas the post-Independence novelists struggled to achieve the right balance between Eastern and Western values, visible in the variable geometry between mythical and realist modes, the post-1981 INE further ideologised this relation by giving it a local versus global dimension. What is generally understood by this new dichotomy opposing local Indianness and global Westernness translates in fact a convergence of the Indian imagination, its story-telling tradition and its disconcerting multiplicity with the input of Western realism, its analytical approach, postmodern fictional techniques and postcolonial theoretical paradigms.

To analyse Indian literary productions in relation to 'global culture' or to the 'global novel' is to make choices among the plurality of Indian cultures and literatures and then to promote those choices as emblematic of Indian literature as a whole. Most of the time this selection has favoured the INE, which enjoys fashionable status on international book markets. INE fully exemplifies the operations of globalism in terms of economic factors (sales, profit), cultural visibility (positive reviews, good reception, international awards) and the promotion of cultural hybridity and dialogue. However, the INE always faces the danger of prosecuting a utopian projection of an idealised essential Indianness into the Western literary world. Trying to find a middle ground between the 'homogenisation and essentialisation of locality,' and a globalism that makes use of electronic media and mass migration as forces that 'seem to impel (and sometimes to compel) the work of the imagination' (Appadurai 1996: 4), the INE, in its most recent productions, has tried to embrace a glocal approach. Thomas Friedman once stated that cultural globalisation will be sustainable only if it 'turns out to be a confederation of distinct cultures and not a homogenisation of them, and if it promotes a more culturally diverse universe, rather than a soulless, standardised globe' (2000: 337). The particular balance that the INE novel has finally managed to achieve, between regional and national realities, between texts written in local languages and texts translated into/written in English, or between local and global values, seems to have placed INE on track towards achieving a balance between an eclectic, inclusive, multi-sided and polyphonic India and the Western literary canon. 


\section{Reference list}

Adiga, A. 2008, The White Tiger. Atlantic Books, London.

Afzal-Khan, F. 1993, Cultural Imperialism and the Indo-English Novel: Genre and Ideology in R.K. Narayan, Anita Desai, Kamala Markandaya and Salman Rushdie. Penn State University Press, University Park, PA.

Anand, M. R. 1935, Untouchable. Arnold Associates, New Delhi.

Anand, M. R. 1936, Coolie. Lawrence and Wishart, London.

Appadurai, A. 1990, 'Disjuncture and Difference in the Global Cultural Economy,' Theory, Culture and Society, vol. 7: 295-310. doi: http://dx.doi.org/10.1177/026327690007002017.

Appadurai, A. 1993, 'The Heart of Whiteness,' Callaloo, On Post-colonial Discourse, A Special Issue, vol. 16, no. 4: 796-807.

Appadurai, A. 1996, Modernity at Large: Cultural Dimensions of Globalisation. University of Minnesota Press, MN.

Ashcroft, B, Griffiths, G. \& Tiffin, H. 2002, The Empire Writes Back: Theory and Practice in PostColonial Literatures. $2^{\text {nd }}$ ed. Routledge, London \& New York. doi: http://dx.doi.org/10.4324/9780203402627.

Bauman, Z. 1989, Globalisation: The Human Consequences. Polity, Cambridge.

Bhattacharya, B. 1947, So Many Hungers! Victor Gollancz, London.

Bhattacharya, B. 1952, Music for Mohini. Crown Publishers, New York.

Bhattacharya, B. 1954, He Who Rides a Tiger. Crown Publishers, New York.

Bhattacharya, B. 1960, A Goddess Named Gold. Crown Publishers, New York.

Bhattacharya, B. 1966, Shadow from Ladhak. Crown Publishers, New York.

Carter, A. 1996, Shaking a Leg: Journalism and Writings. Chatto \& Windus, London.

Chattopadhyay, B. C. 1864, Rajmohan's Wife, serialised in The Indian Field.

Chaudhuri, A. (ed.) 2001, The Picador Book of Modern Indian Literature. Picador/Pan Macmillan, London.

Choudhury, C. 2009, ‘English Spoken Here: How Globalisation is Changing the Indian Novel,' Foreign Policy Magazine, November-December: 96-97. Online, available: http://foreignpolicy.com/2009/10/15/english-spoken-here/ [Accessed 23 July 2011].

Coetzee, J. M. 2004, Elizabeth Costello. Penguin, New York.

Cousins, J. H. (ed.) 1883, Specimen Compositions from Native Students. N. p., Calcutta.

D’Cruz, G. 2003, My Two Left Feet: The Problem of Anglo-Indian Stereotypes in Post-Independence Indo-English Fiction. Sage, London, Thousand Oaks, CA, \& New Delhi.

Desai, A. 1994, 'The Other Voice,’ Transitions, no. 64: 77-89.

Dugger, C. W. 2001, 'High-Stakes Showdown; Enron’s Fight Over Power Plant Reverberates Beyond India,’ New York Times, 20 March. Online, available:

http://www.nytimes.com/2001/03/20/business/high-stakes-showdown-enron-s-fight-over-powerplant-reverberates-beyond-india.html [Accessed 24 March 2014].

Featherstone, M. 1990, Global Culture: Nationalism, Globalisation and Modernity. Sage, London.

Featherstone, M. 1995, Undoing Culture, Globalisation, Postmodernism and Identity. Sage, London.

Friedman, T. 2000, The Lexus and the Olive Tree: Understanding Globalization. Random House, New York.

Gokak, V. K. (ed.) 1970, The Golden Treasury of Indo-Anglian Poetry. Sahitya Akademi, New Delhi.

Harvey, D. 1989, The Condition of Postmodernity. Blackwell, Oxford.

Iwabuchi. K. 2002, Recentering Globalisation: Popular Culture and Japanese Transnationalism. Duke University Press, Durham, NC. doi: http://dx.doi.org/10.1215/9780822384083.

Iyengar, S. 1962, Indian Writing in English. Asia Publishing House, London.

Jameson, F. 1981, The Political Unconscious: Narrative as a Socially Symbolic Act. Cornell University Press, Ithaca.

Jhabvala, R. P. 1975, Heat and Dust. John Murray, London.

Jussawalla, F. \& Dasenbrock, R. W. 1992, Interviews with Writers of the Post-Colonial World. University Press of Mississippi, Jackson, MS.

Kachru, B. 1996, 'World Englishes: Agony and Ecstasy,' Journal of Aesthetic Education, Special Issue: Distinguished Humanities lectures II. (Summer), vol. 30, no. 2: 135-155.

Khair, T. 2001, Babu Fictions: Alienation in Contemporary Indian English Novels. Oxford University Press, Oxford.

Markandaya, K. 1954. Nectar in a Sieve. Signet Books, New York.

Markandaya, K. 1955, Some Inner Fury. Jaico, Bombay.

Markandaya, K. 1966. A Handful of Rice. The John Day Company, New York. 
Mehotra, A. K. 2003, 'Introduction,’ A History of Indian Literature in English, (ed.) A. K. Mehotra. C. Hurst \& Co., London: 1-26.

Meyrowitz, J. 2004, The Rise of Glocality: New Senses of Place and Identity in the Global Village. Online, available: http://www.fil.hu/mobil/2004/meyrowitz_webversion.doc [Accessed 24 March 2014].

Moretti, F. 2000, 'Conjectures on World Literature,' New Left Review, no. 1: 54-68.

Mukherjee, M. 1974, The Twice Born Fiction: Themes and Techniques of the Indian Novel in English. Arnold Heinemann, New Delhi.

Naik, M. K. 1982, A History of Indian English Literature. Sahitya Akademi, New Delhi.

Naik, M. K. (ed.) 2009 (1979), Aspects of Indian Writing in English. Macmillan, New Delhi.

Naipaul, V. S. 1981, An Area of Darkness: A Discovery of India. Vintage Books, New York.

Narayan, R. K. (1979) 2009, 'English in India: The Process of Transmutation,' in Aspects of Indian Writing in English, (ed.) M. K. Naik, New Delhi: Macmillan Publishers India Ltd: 19-23.

Rao, R. 1963 [1938], Kanthapura. Oxford University Press, Bombay.

Rao, R. 1996, The Meaning of India. Vision Books, New Delhi.

Raveendran, P. P. 2006, 'Genealogies of Indian Literature,' Political and Economic Weekly, vol. 41, no. 25: 2558-2563.

Robertson, R. 1992, Globalisation: Social Theory and Global Culture. Sage, London.

Rupert, M. 2000, Ideologies of Globalisation: Contending Visions of a New World Order. Routledge, London.

Rushdie, S. 1991, Imaginary Homelands. Granta Books, London.

Rushdie, S. 1995, Midnight's Children. Vintage, London.

Rushdie, S. \& West, E. (eds) The Vintage Book of Indian Writing, 1947-1997. Vintage, London.

Saïd, E. 1978, Orientalism. Random House, New York.

Singer, P. 2004, One World: The Ethics of Globalisation. Yale University Press, New Haven, CT.

Singh, K. 1956, Train to Pakistan. Chatto \& Windus, London.

Siskind, M. 2010, 'The Globalisation of the Novel and the Novelisation of the Global. A Critique of World Literature,' Comparative Literature (Winter), vol. 62, no. 4: 336-360.

Spivak, G. C. 1996, 'How to Read a “Culturally Different” Book,' in Colonial Desire/Post-Colonial Theory, (eds) F. Barker, P. Hulme \& M. Iversen. St. Martin’s Press, New York: 126-127.

Straubhaar. J. D. 2007, World Television: from Global to Local. Sage, Thousand Oaks CA.

Suleri, S. 1994, The Rhetoric of English India. Penguin Books, India.

Swarup, V. 2005, Q\&A. Doubleday, New York.

Tagore, R. 1912, Gitanjali. India Society, London.

Tomlinson, J. 1999, Globalisation and Culture. Polity Press, Cambridge.

Trivedi, H. \& Meenakshi, M. (eds) 2000, Interrogating Post-colonialism: Theory, Text and Context. Glorious Printers, Delhi. 